\title{
AN EXPERIENCE OF FACILITY-BASED MANAGEMENT OF SEVERE ACUTE MALNUTRITION IN CHILDREN AGED BETWEEN 0-59 MONTHS ADOPTING THE WORLD HEALTH ORGANIZATION RECOMMENDATIONS AT NUTRITION REHABILITATION CENTRE, ANANTHAPURAMU
}

\author{
N. Praveen Deen Kumar'1, B. Praveena ${ }^{2}$
}

${ }_{1}^{1}$ Assistant Professor, Department of Paediatrics, Government Medical College, Ananthapuramu.

${ }^{2}$ Tutor, Department of Microbiology, Government Medical College, Ananthapuramu.

ABSTRACT
BACKGROUND
Severe Acute Malnutrition (SAM) increases significantly the risk of death in children under five years of age. It can be an indirect
cause of child death by increasing the case fatality rate in children suffering from common illness such as diarrhoea, pneumonia.

\section{AIMS}

The aim of this study is to know the effectiveness of facility based management of children with Severe Acute Malnutrition at Nutrition Rehabilitation Centres (NRCs).

\section{SETTINGS AND DESIGN}

The study was done in the Department of Paediatrics, Government General Hospital at Ananthapuramu as a prospective observational study.

\section{METHODS AND MATERIALS}

A total of 195 patients were selected under Severe Acute Malnutrition as per WHO Child Growth Standards by observing for bilateral pitting oedema and/or MUAC $<115 \mathrm{~mm}$ and/or Weight-for-height/length (Z-Score) below -3 SD and/or visible wasting before admission into NRCs. Statistical analysis was done using Graph pad software.

\section{OUTCOMES}

Death, Default, Discharge and Recovery Rates.

\section{RESULTS}

The mean age group of SAM children was 15.4 months; $81.5 \%$ of SAM children were presented with medical complications. Of the 195 subjects, 2 were referred. Out of 193 program exits, 5 (2.6\%) children died, 35 (18.1\%) children defaulted and 153 (79.3\%) children were discharged. Out of the 153 discharged children, 103 (67.3\%) attained target weight gain >_15\% admission weight, while $50(32.7 \%)$ did not attain target weight gain (non-recovered).

\section{CONCLUSION}

This study will help to improve the functional activities of NRCs. Conducting audits after such studies will aid in implementation of newer guidelines, which will enhance the functional outcome of NRCs. Such NRCs will greatly help to reduce the under-five child mortality rate.

\section{KEYWORDS}

Severe Acute Malnutrition, Nutrition Rehabilitation Centres, Weight-for-Height/Length.

HOW TO CITE THIS ARTICLE: Kumar NPD, Praveena B. An experience of facility-based management of severe acute malnutrition in children aged between 0-59 months adopting the world health organization recommendations at nutrition rehabilitation centre, Ananthapuramu. J. Evolution Med. Dent. Sci. 2016;5(32):1744-1748, DOI: 10.14260/jemds/2016/411

\section{INTRODUCTION}

Malnutrition is a general term. It most often refers to undernutrition resulting from inadequate consumption, poor absorption or excessive loss of nutrients, but the term can also encompass over nutrition resulting from intake of over nutrition.

Severe Acute Malnutrition is defined by very low weightfor-height/length (Z-score below -3 SD of the median WHO

Financial or Other, Competing Interest: None.

Submission 29-02-2016, Peer Review 27-03-2016,

Acceptance 01-04-2016, Published 21-04-2016.

Corresponding Author:

Dr. N. Praveen Deen Kumar,

Assistant Professor,

Department of Paediatrics,

Government Medical College,

Ananthapuramu.

E-mail: praveendeen@gmail.com

DOI: $10.14260 /$ jemds/2016/411 child growth standards), and/or a upper arm circumference (MUAC) $<115 \mathrm{~mm}$ and/or by the presence of nutritional oedema. SAM increases significantly the risk of death in children under five years of age. It can be an indirect cause of child death by increasing the case fatality rate in children suffering from common illness such as diarrhoea and pneumonia.

Moderate Acute Malnutrition was in about 60 million people and Severe Acute Malnutrition documented in 13 million people worldwide.[1] According to NFHS III in India, prevalence of Severe Acute Malnutrition (SAM) is $6.4 \%$ in children below 5 years with 100 focus districts having high prevalence of malnutrition being situated in 6 states: Bihar, Jharkhand, Madhya Pradesh, Rajasthan, Orissa and Uttar Pradesh.[2-4] Morality rate associated with moderate wasting is about 30 to 148 per 1000 children per year and severe wasting is about 73 to 187 per 1000 children per year.[5,6] 
Children who are severely wasted are 9 times more likely to die than well-nourished children. Major killer of under-five children is Severe Acute Malnutrition (SAM), which is a neglected health condition. [7] SAM is mainly prevalent in many poor countries such as Malawi. SAM is the commonest reason for paediatric hospital admission.[8]

Children suffering from undernutrition being their lives with a significant disadvantage. Malnutrition significantly contributes to under-five mortality, as undernourished child has increased susceptibility to infections and also plays an important role in growth retardation and impaired psychosocial and cognitive development. The degree of cognitive impairment is directly related to the severity of stunting and iron deficiency anaemia.

SAM is an important preventable and treatable cause of morbidity and mortality in children below five years of age in India. Nutrition Rehabilitation Centre (NRC) is a unit in a health facility, where children with Severe Acute Malnutrition (SAM) are admitted and managed. A number of state governments have taken the lead and are in the process of scaling up the establishment of NRCs with the intention to improve the quality of care being provided to children with SAM and to reduce the child mortality.

The aim of this study is to know the outcome of children with Severe Acute Malnutrition after management at Nutrition Rehabilitation Centres (NRCs). This will help to enhance the activities of NRCs and also to reduce the morbidity and mortality of under-five children.

\section{MATERIALS AND METHODS}

The study was done in the Department of Paediatrics, Government General Hospital at Ananthapuramu as an observational study. Informed consent has been taken from their parents or guardians and this study was approved by Ethical Committee.

Study period was from October 2014 to September 2015. A total of 195 patients were selected under Severe Acute Malnutrition as per WHO Child Growth Standards.[9] by observing for bilateral pitting oedema and/or MUAC $<115 \mathrm{~mm}$ and/or Weight-for-Height/Length (Z-score) below -3SD and/or visible wasting among 6-59 months and in infants $<6$ months also by noticing feeble to suckle effectively. These children also underwent general examination for detection of any medical complications like respiratory tract infections, malaria, tuberculosis, diarrhoea, altered behaviour, persistent vomiting, fever or hypothermia, hypoglycaemia and severe anaemia by following Integrated Management of Neonatal and Childhood Illness (IMNCI) guidelines. Those SAM children with medical complications underwent routine significant examinations.

All 195 patients with age group of 0-59 months were referred to Nutrition Rehabilitation Centre (NRC) as per new guidelines. At NRC, 24 hours service and care was provided to SAM children by treating the medical complications, therapeutic feeding, sensory stimulation and emotional care, and also counselling has been given to mothers on appropriate feeding, care and hygiene and followup for children discharged from NRC.

Children with medical complications were investigated with appropriate lab investigations and treated accordingly. As they have poor appetite, they were fed with F-75 containing
$75 \mathrm{kcal} / 100 \mathrm{~mL}$ and $0.9 \mathrm{~g}$ protein/100 $\mathrm{mL}$ every two hours until they enter into rehabilitation phase where there is return of appetite. Children with uncomplicated SAM or children with complicated SAM in rehabilitation phase were fed with F-100, contains $100 \mathrm{kcal}$ and $2.9 \mathrm{~g}$ protein/ $100 \mathrm{~mL}$ six times a day for 48 hours to initiate rapid weight gain. After 4 days the feed was changed with locally prepared foods like kichidi, dal on alternate days along with F-100.

Micronutrients such as Vitamin A (Orally on day 1), Folic acid ( $5 \mathrm{mg}$ on day 1 and $1 \mathrm{mg} /$ day, Iron $(3 \mathrm{mg} / \mathrm{kg} / \mathrm{d}$ after first week), Zinc ( $2 \mathrm{mg} / \mathrm{kg} / \mathrm{d})$ and Magnesium were administered to all NRC children for entire period of stay.

Counselling was given to parents about hygienic practices like hand washing, feeding utensils cleanliness, preparation of foods and bonding between mother and baby. Children at NRC were discharged only after attaining discharge criteria: a) Child has no oedema or any infections, b) Return of social smile, c) Eating at least $120-130 \mathrm{kcal} / \mathrm{kg}$ weight/day, d) Completed immunization appropriate for age, e) Caretakers sensitized to home care, f) Achieved target weight gain (weight gain of $15 \%$ of admission weight).

After discharge from NRC, caretakers were advised to come for follow-up regularly up to six weeks. First follow-up after one week, 2 nd after 15 days of first one and 3rd after 15 days of second one. In the meantime, local workers either ICDS or NRHM workers were advised to follow child and benefit them from ICDS supplementary nutritional program.

Data regarding details of SAM children enrolled in NRC was entered and analysed. All this data was kept unlinked anonymously.

\section{STATISTICAL ANALYSIS}

Statistical analysis was done using Graph pad software. The P value $<0.05$ was considered significant.

\section{RESULTS}

195 children with Severe Acute Malnutrition were selected in the age group of 0 to 59 months from the ward and those attending Paediatric Outpatient Department (OPD) who fulfils admission criteria. 195 children admitted to NRC were assessed and the results were tabulated.

The mean age group of SAM children was 15.4 months. The incidence of severe wasting Mid Upper Arm Circumference (MUAC), Weight-for-Height/Length Z-Score, were depicted in Table No. 1.

Among 195 patients, 36 children were presented with only SAM (Fig. No. 3) and remaining 159 children about (81.5\%) were presented with SAM associated with medical complications (Fig. No. 2). Various other demographic data, which was analysed among SAM children admitted to NRC was given in Table No. 2.

Of the 195 subjects, 2 were referred. Out of the remaining 193 children, 5 (2.6\%) children died, 35(18.1\%) children were defaulted and $153(79.3 \%)$ children were discharged. Out of the 153 discharged children, 103 (67.3\%) attained target weight gain $\geq 15 \%$ (recovered), while 50 (32.7\%) did not attain target weight gain (non-recovered) (Table No. 3).

Out of the 153 discharged children who were treated in NRC, only 44 (13.1\%) children came for all the three followup visits, $30(19.6 \%)$ came for two followup visits and 146 (95.4\%) came for only one followup visit (Fig. No. 1). 


\begin{tabular}{|c|c|c|c|}
\hline $\begin{array}{c}\text { Sl. } \\
\text { No. }\end{array}$ & $\begin{array}{c}\text { Characters } \\
\text { Assessed before } \\
\text { Treatment }\end{array}$ & $\begin{array}{c}\text { Total No. } \\
\text { of Patients }\end{array}$ & $\begin{array}{c}\text { Percentage } \\
\text { (\%) }\end{array}$ \\
\hline 1 & Severe Wasting & 175 & 89.7 \\
\hline 2 & MUAC $<115 \mathrm{~mm}$ & 68 & 34.9 \\
\hline 3 & $\begin{array}{c}\text { Weight-for- } \\
\text { Height/Length Z- } \\
\text { Score }<3 \text { SD }\end{array}$ & 114 & 58.5 \\
\hline 4 & $\begin{array}{c}\text { Both MUAC }<115 \\
\text { mm and Z-Score }<3 \\
\text { SD }\end{array}$ & 37 & 18.9 \\
\hline 5 & $\begin{array}{c}\text { Both MUAC }<115 \\
\text { mm and Z-Score }<2 \\
\text { SD }\end{array}$ & 181 & 92.8 \\
\hline \multicolumn{3}{|c|}{$\begin{array}{c}\text { Total } \\
\text { Table 1: Incidence of Characters those } \\
\text { Assessed before Treatment at NRC }\end{array}$} \\
\hline
\end{tabular}

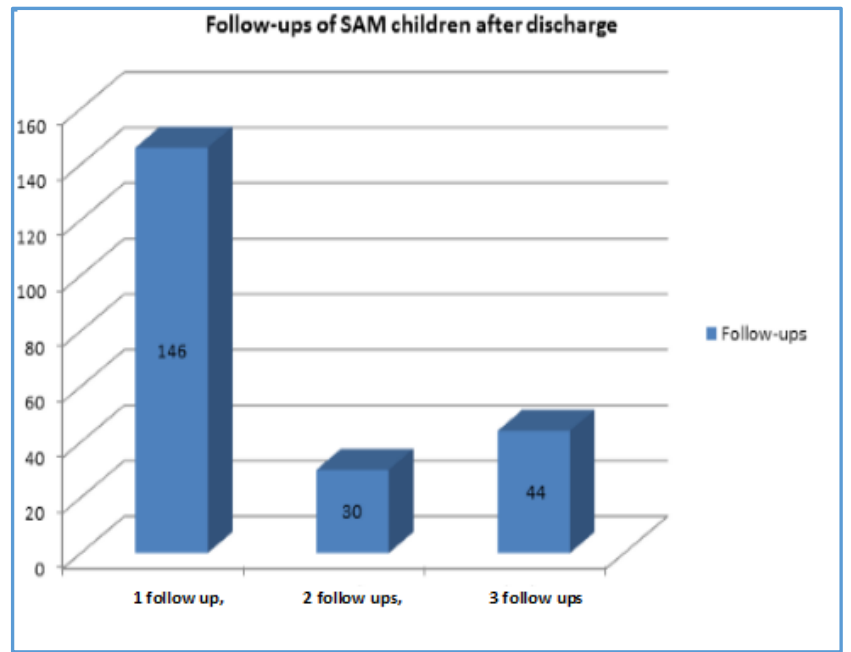

Fig. 1: Showing attending Follow-Ups after Discharge of SAM Children

\begin{tabular}{|c|c|c|c|}
\hline \multicolumn{2}{|c|}{$\begin{array}{c}\text { Demographic } \\
\text { Parameters }\end{array}$} & $\begin{array}{c}\text { Total } \\
\text { No. of } \\
\text { Patients }\end{array}$ & $\begin{array}{c}\text { Percentage } \\
(\%)\end{array}$ \\
\hline \multicolumn{2}{|c|}{ Girls } & 113 & 57.9 \\
\hline \multirow{6}{*}{ Age } & $<6$ months & 7 & 3.6 \\
\hline & 6-11 months & 41 & 21 \\
\hline & 12-23 months & 84 & 43 \\
\hline & 24-35 months & 35 & 17.9 \\
\hline & 36-47 months & 14 & 7.2 \\
\hline & 48-59 months & 14 & 7.2 \\
\hline \multirow{4}{*}{ Caste } & ST & 13 & 6.7 \\
\hline & SC & 45 & 23.1 \\
\hline & $\mathrm{BC}$ & 125 & 64.1 \\
\hline & OC & 10 & 5.1 \\
\hline \multirow{3}{*}{$\begin{array}{l}\text { Clinical } \\
\text { Findings }\end{array}$} & $\begin{array}{c}\text { Bilateral pitting } \\
\text { oedema }\end{array}$ & 11 & 5.6 \\
\hline & $\begin{array}{l}\text { With severe } \\
\text { wasting }\end{array}$ & 175 & 89.7 \\
\hline & $\begin{array}{l}\text { With medical } \\
\text { complications }\end{array}$ & 159 & 81.5 \\
\hline \multicolumn{4}{|c|}{$\begin{array}{l}\text { Table 2: Demographic Data Regarding } \\
\text { SAM Children Admitted to NRC }\end{array}$} \\
\hline
\end{tabular}

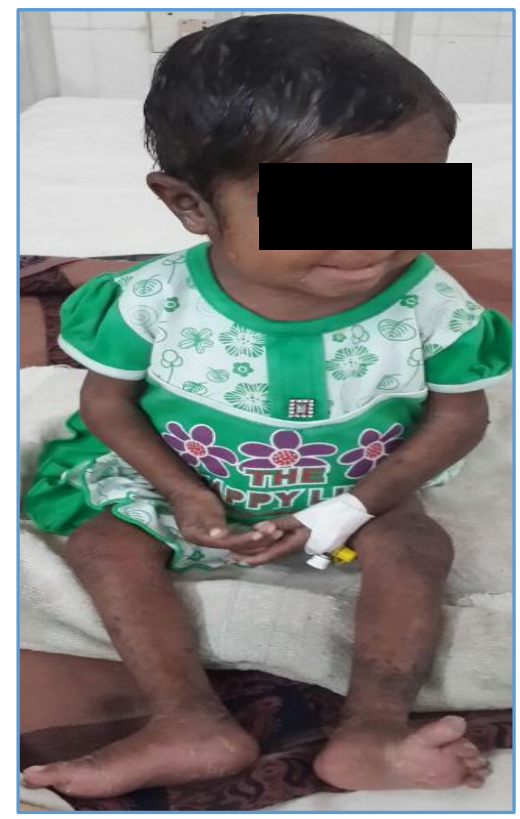

Fig. 2: SAM Child with Medical Complication (Diarrhea)

\begin{tabular}{|c|c|c|}
\hline Category & $\begin{array}{c}\text { Total No. of } \\
\text { Patients }\end{array}$ & $\begin{array}{c}\text { Percentage } \\
\text { (\%) }\end{array}$ \\
\hline Admitted & 195 & 100 \\
\hline Exits & 193 & $99 \%$ \\
\hline Referred & 2 & $1 \%$ \\
\hline Exits & 5 & $2.6 \%$ \\
\hline Deaths & 35 & $18.1 \%$ \\
\hline Defaulters & 153 & $79.3 \%$ \\
\hline Discharged & 103 & $67.3 \%$ \\
\hline Discharged & 50 & $32.7 \%$ \\
\hline Recovered & & \\
\hline $\begin{array}{c}\text { Non- } \\
\text { recovered }\end{array}$ & \multicolumn{2}{|c|}{ Table 3: Data of Study Children } \\
\hline \multicolumn{2}{|c|}{} \\
\hline
\end{tabular}

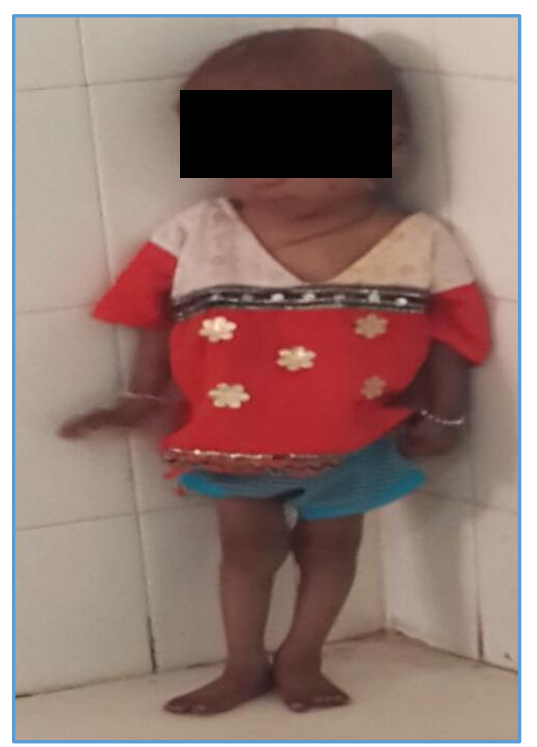

Fig. 3: SAM Child without Medical Complication 


\section{DISCUSSION}

SAM is a global health problem, more prevalent in the developing countries. Prevalence of SAM was 3.6\% (0.95 CI: $1.9,6.1) .[10]$ Severe malnutrition represents only the tip of the iceberg. Care of children with severe SAM is quite a challenging task, as they often present with life-threatening medical emergencies.

This study has found the outcome of management of SAM children at NRC. The mean age group of SAM children was 15.4 months. As in this study SAM children with medical complications were more about $81.5 \%$, treated with special care by improving the therapeutic feeding and regular monitoring for infections at NRC when compared to the children with only SAM as to decrease the child fatality rate. Singh K et al.[11] reported uncomplicated SAM children was about $58.2 \%$ and they were treated with special care as per International Guidelines.[12]

In this study, death rate was $2.6 \%$ and survival rate was $97.4 \%$. The program achieved favourable outcomes when compared with national and international standards $[13,14]$, which is a primary objective of NRC to reduce case fatality rate ( $<10 \%$ child deaths). $32.7 \%$ did not attain target weight gain; this can be improved by providing therapeutic foods according to protocols and more focus on complicated SAM children by giving appropriate health care.

In the present study $18.1 \%$ were defaulters which is above national and international standards care $(<15 \%)$, which is in line with Singh K et al., Mamidi RS et al.[17], but in contrast to this Manisha Maurya et al.[18] who reported only $4.4 \%$. Higher defaulter rate may be due to various issues in communities like lesser belief on NRC and also mainly due to illiteracy, lower socioeconomic status. Recovery rate in this study was $67.3 \%$ which is not in an acceptable range, which coincides with Manisha Maurya et al.[18] and Singh K et al.[11], but Teferi et al.[15] and Hossain et al..[16] documented that their recovery rate is $>75 \%$.

Using the new WHO child growth standards in developing country situations results in a 2-4 times increase in the number of infants and children falling below -3 SD weight for height/length compared to using the former NCHS reference.

This study will help to improve the functional activities of NRCs. Conducting audits after such studies will aid in implementation of newer guidelines, which will enhance the functional outcome of NRCs. Such NRCs will greatly help to reduce the under-five child mortality rate.

\section{CONCLUSION}

We conclude that NRCs are effective in reducing mortality related to malnutrition. Patients can be discharged on request before the discharge criteria are met and they should be adequately counselled regarding the complications of malnutrition to decrease the defaulter rate. At the same time, NRCs should be attached with the community health schemes for proper management and follow-ups.

\section{REFERENCES}

1. Collins S, Dent N, Binns P, et al. Management of severe acute malnutrition in children. Lancet 2006; 368 (9551) :1992-2000.
2. Operational guidelines on facility based management of children with severe acute malnutrition, ministry of health and family welfare, Government of India, 2011. Accessed February 25, 2014. Available from: http://www.nihf.org/NCHRC-Publications/ Operational Guidelines.

3. HUNGaMA fight for hunger and malnutrition, the HUNGaMA survey report, 2011. Accessed February 27, 2014. Available from: http://hungamaforchange.org/hungamBKDec11LR.pdf.

4. International institute for population sciences (IIPS) and Macro International. 2007. National Family Health Survey (NFHS-3), India: 2005-06; Volume I. Accessed on 04 Jan 2013. Available from:

http://pdf.usaid.gov/pdf_docs/PNADK385.pdf..

5. Pelletier DL. The relationship between child anthropometry and mortality in developing countries: implications for policy, programs and future research. J Nutr 1994;124(10):2047S-81S.

6. Chen LC, Chowdhury A, Huffman SL. Anthropometric assessment of energy-protein malnutrition and subsequent risk of mortality among preschool children. Am J Clin Nutr 1980;33(8):1836-45.

7. Jones G, Steketee RW, Black RE, et al. How many child deaths can we prevent this year? The Lancet 2003;362(9377):65-71.

8. Bhan MK, Bhandari N, Bhal R. Management of the severely malnourished child: perspective from developing countries. BMJ 2003;326(7381):146-51.

9. World Health Organization (WHO) multicentre growth reference study growth. World Health Organization (WHO) child growth standards based on length/height, weight and age. Acta Paediatrica 2006;450:76-85.

10. Hemant Deepak Shewade, Bhuvaneswary Sundera murthy, Niranjana Jayakumar, et al. Prevalence of severe acute malnutrition (SAM) among under-five children: a community-based cross-sectional study from puducherry, India. Indian Journal of Maternal and Child health 2012;15(1).

11. Singh K, Badgaiyan N, Ranjan A, et al. Management of children with severe acute malnutrition: experience of nutrition rehabilitation centers in Uttar Pradesh, India. Indian Pediatrics 2014;51(1):21-5.

12. World Health Organization (WHO), World Food Program (WFP), united nations standing committee on nutrition (UNSCN), united nations children's fund (UNICEF), community based management of severe acute malnutrition: a joint statement by the World Health Organization, the world food program, the united nations standing committee on nutrition and the united nations children's fund, Geneva, Switzerland, 2007.

13. The Sphere Project. Humanitarian charter and minimum standards in humanitarian response. The Sphere Project Publications; 2011;3rd edition.

14. Ministry of Health and Family Welfare, Government of India. Operational guidelines on facility based management of children with severe acute malnutrition. National rural Health Mission, Ministry of health and Family Welfare, New Delhi, India, 2011. 
15. Teferi E, Lera M, Sita S, et al. Treatment outcome of children with severe acute malnutrition admitted to therapeutic feeding centers in Southern Region of Ethiopia. Ethiopion J Health Dev 2010;24(3):234-8.

16. Hossain MI, Dodd NS, Ahmed T, et al. Experience in managing severe malnutrition in a government tertiary treatment facility in Bangladesh. J Health Popul Nutr 2009;27(1):72-9.
17. Mamidi RS, Kulkarni B, Radhakrishna KV, et al. Hospital based nutrition rehabilitation of severely undernourished children using energy dense local foods. Indian Pediatr 2010;47(8):687-93.

18. Manisha Maurya, Singh DK, Ruchi Rai, et al. An experience of facility-based management of severe acute malnutrition in children aged between 6-59 months adopting the world health organization recommendations. Indian Pediatr 2014;51(6):481-3. 